на захворюваність ЗН легенів як для шахтарів основних професій, так i для професій допоміжних виробництв.

\title{
Література:
}

1. ICRP. Radiological protection against radon exposure. ICRP Publicatoin 126. Annajs of the ICP 43(3). International Commission on Radiological Protection Elsevier Ltd., 2014.

2. Іщенко Л.О. Ризик опромінення радоном та аналіз фактичної захворюваності на рак легень серед населення м. Кривого Рогу. Український журнал $з$ проблем медицини праці. 2019. 1(58). С. 52-60. doi: https:// doi.org/10.33573/ujoh2019.01.052

3. Ishchenko L., Kovalchuk T. Radiation protection at the iron mines in the conditions of technogenically increased sourses of natural origin. Ukraine journal of Modern problems of Toxicology. 2020. № 1(88). C. 61-66. doi: https:// doi.org/10.33273/2663-4570-2020-88-1-65-70

DOI https://doi.org/10.30525/978-9934-26-006-3-28

\section{RESEARCH OF CONSUMERS OF ANTIANEMIC DRUGS PRESENTED ON THE PHARMACEUTICAL MARKET OF UKRAINE}

Kobets M. N.

Candidate of Pharmaceutical Sciences, Associate Professor, Associate Professor at the Department of Pharmaceutical Management and Marketing National University of Pharmacy

Martyniuk T. V.

Candidate of Pharmaceutical Sciences, Associate Professor at the Department of Cosmetology and Aromology National University of Pharmacy

Filiptsova $\mathbf{O}$. V. Doctor of Biological Sciences, Professor at the Department of Cosmetology and Aromology National University of Pharmacy

Kharkiv, Ukraine

Accordingly to the World Health Organization (WHO), anemia is a condition characterized by a decrease in hemoglobin (less than $130 \mathrm{~g} / \mathrm{l}$ in males and $120 \mathrm{~g} / \mathrm{l}$ in females). The main causes of anemia include 
malnutrition (most often iron and folic acid deficiency in food), hereditary, parasitic, infectious diseases. In recent years, the prevalence of anemia in people over 60 years of age has been particularly pronounced. Population studies have shown a direct correlation between anemia and age. Moreover, the prevalence of anemia is higher in women under 65 years of age, while among males it occurs in the older age group. Probably, the explanation for this pattern is that iron loss in females is associated with excessive menstrual bleeding and childbirth, in contrast to males, whose incidence of anemia increases in the old age $[1$, p. 52]. Accordingly to the WHO, in countries with economies in transition, anemia is observed in an average of $56 \%$ of pregnant females, and in developed countries in $18 \%$ accordingly. The most common types of anemia are iron deficiency, vitamin $\mathrm{B}_{12}$-folate deficiency and erythropoietin deficiency anemia.

The aim of the work was the study of consumers of antianemic drugs presented on the pharmaceutical market of Ukraine.

Research methods. A survey of pharmacy visitors was conducted in Chuguev, Kharkiv region. 145 consumers of antianemic drugs were interviewed. The questionnaire contained three parts: introduction; requisites: characteristics of the respondent (place of residence, age, sex, marital status, social status, level of education, number of family members, average monthly income per family member); main part (questions to the respondent) [2, p. 83].

Research results. The majority of respondents were females aged 21-40. Studies have identified the most important characteristics of these drugs for patients with anemia on a 10-point Likert scale. According to the results of the survey, consumers gave the highest number of points to the following criteria: safety (9.87), efficacy (9.73), ease of use (8.42) and price of the drug (7.78). These criteria are confirmed by the fact that despite the possible increase in the price of antianemic drugs, most respondents will continue to buy the drug they were previously treated with. The survey of consumers determined the level of satisfaction of respondents with the effectiveness, duration, cost of treatment, and the absence of side effects from the treatment of certain antianemic drugs. In general, the values of the assessments of these criteria are quite high, despite the fact that some of these drugs belong to the group of high-value drugs. This can be explained by the fact that when prescribing a particular drug, the doctor takes into account the cost of treatment with the drug and correlates it with the solvency of the patient. The most attractive drugs were Maltofer, Ferrum Lek, Sorbifer Durules, Folic Acid, Tardiferon, Gino-tardiferon and Maltofer Fol. In general, the level of satisfaction of consumer demand for antianemic drugs ranges from 70 to $100 \%$, which indicates a wide range and satisfactory effectiveness of this group of drugs. However, it should be noted that of the ten most prescribed antianemic drugs by doctors, only two are domestically produced drugs. Therefore, the problem of developing new antianemic drugs 
of domestic production with high efficiency and wide variation of dosage forms remains a topical issue.

\title{
References:
}

1. Князькова I.I. Сучасні підходи до діагностики анемій. Ліки Украӥни. № 7. 2010. С. 52-56.

2. Мнушко 3.Н., Пестун И.В. Теория и практика маркетинговых исследований в фармации: монография. Харьков: НФаУ, 2008. 308 с.

DOI https://doi.org/10.30525/978-9934-26-006-3-29

\section{EVALUATION OF ANTITUMOR EFFECT OF OXAMATE ON METASTATICALLY ACTIVE CELLS}

\author{
Kolesnik D. L. \\ Candidate of Biological Sciences,
}

Senior Researcher at the Laboratory of Molecular and Cellular Mechanisms of Metastasizing

R.E. Kavetsky Institute of Experimental Pathology, Oncology and

Radiobiology of National Academy of Sciences of Ukraine

Pyaskovskaya O. N.

Candidate of Biological Sciences,

Senior Researcher of Laboratory of Molecular and Cellular Mechanisms

of Metastasizing

R.E. Kavetsky Institute of Experimental Pathology, Oncology and

Radiobiology of National Academy of Sciences of Ukraine

\section{Solyanik G. I.}

Doctor of Physico-Mathematical Sciences, Professor,

Head of Laboratory of Molecular and Cellular Mechanisms of Metastasizing

R.E. Kavetsky Institute of Experimental Pathology, Oncology and

Radiobiology of National Academy of Sciences of Ukraine

Kyiv, Ukraine

It is known that high dependence on glycolysis, even in the presence of oxygen (a phenomenon known as the Warburg effect) is one of the unique features of malignant cells. As the main pathway of energy production, glycolysis provides malignant cells with growth benefits and represents a wide range of potential targets for successful therapeutic intervention $[1,2]$. 116 